\title{
Технологічні та методичні умови реалізації моделі організаційно-методичного забезпечення дитячого футбольного клубу
}

\author{
Рудольф Сухомлинов, Тарас Блистів
}

\author{
Національний університет фізичного виховання і спорту України, Київ, Україна
}

Анотація. У статті теоретично обгрунтовано, розроблено та експериментально перевірено модель організаційно-методичного забезпечення оздоровчо-рекреаційної діяльності дітей старшого дошкільного віку в умовах дитячих футбольних клубів, що включає організаційний, діагностичний, програмно-методичний та контрольний блоки, та опрацьовано технологічні і методичні умови їі реалізації для підвищення безпечності та ефективності занять 3 дітьми дошкільного віку. Мета. Розробити структуру і зміст фрітнес-програми для дітей старшого дошкільного віку. Методи. Теоретичний аналіз фрахової науково-методичної літератури та документальних матеріалів, соціологічні, педагогічні методи дослідження, метод кваліметрії, методи математичної статистики. Результати. Визначено такі технологічні умови для реалізації організаційно-методичного забезпечення оздоровчо-рекреаційних занять в умовах дитячих футбольних клубів: вивчення наявної матеріально-технічної бази, ознайомлення та опис простору, споруд, інвентарю й обладнання, які можуть бути використані для оздоровчо-рекреаційних занять; опитування батьків для визначення спрямованості програми з урахуванням віку, інтересів, очікувань та потреб; опис оздоровчорекреаційної програми для дітей старшого дошкільного віку. Основними методичними умовами виступали: урахування вихідного рівня показників фрізичного стану дітей старшого дошкільного віку, належний первинний, оперативний та поточний лікарсько-педагогічний контроль; урахування потреб дітей та запитів родин у спрямованості оздоровчих занять створення повного програмного супроводу оздоровчо-рекреаційних занять; підвищення фахової компетентності та кваліфікації, методичний супровід тренерів, які проводять заняття за запропонованою програмою, створення оптимальних умов для роботи дитячих тренерів; підвищення педагогічної грамотності батьків з питань здоров'язбереження; створення сприятливих умов для особистісного становлення та творчої самореалізації дітей, залучених до занять; гнучкість та мобільність програми в реагуванні на зміни, які відбуваються з дітьми у процесі оздоровчо-рекреаційних занять.

Ключові слова: дитячі фрутбольні клуби, умови, модель, організаційно-методичне забезпечення

\section{Rudolf Sukhomlinov, Taras Blystiv}

\section{TECHNOLOGICAL AND METHODOLOGICAL CONDITIONS \\ FOR THE IMPLEMENTATION OF THE MODEL OF ORGANIZATIONAL} AND METHODOLOGICAL SUPPORT OF CHILDREN'S FOOTBALL CLUB

Abstract. The article theoretically substantiates the developed and experimentally tested model of organizational and methodological support of health-related and recreational activities of over-fives in children's football clubs, which includes organizational, diagnostic, programmethodical and control units, and developed technological and methodological conditions for its implementation to improve the safety and effectiveness of classes for preschool children. Objective. Develop the structure and content of a fitness program for over-fives. Methods. Theoretical analysis of professional scientific and methodical literature and documentary materials, sociological, pedagogical research methods, qualimetry method, methods of mathematical statistics. Results. The following technological conditions for the implementation of organizational and methodological support of health-related and recreational activities in children's football clubs have been determined: study of the available material and technical base, acquaintance and description of space, facilities, inventory and equipment that can be used for health-related and recreational activities; survey of parents to determine the direction of the program, taking into

Sukhomlinov R., Blystiv T. Technological and methodological conditions for the implementation of the model of organizational and methodological support of children's football club. Theory and Methods of Physical education and sports. 2021: 1: 90-94

DOI: 10.32652/tmfvs.2021.1.90-94
Вступ. Незважаючи на різноманітність програм, що впроваджуються у закладах дошкільної освіти, проблема вдосконалення фрізичного виховання дітей, підвищення рівня їхньої рухової активності залишається актуальною $[1,3,4,13,17,18]$. Серед спортивних ігор фрутбол є одним 3 найбільш привабливих видів рухової активності дітей [2, 5, 8, 12]. Проте, у теорії і методиці фрізичного виховання дітей дошкільного віку навчання елементів гри у футбол $є$ одним 3 найменш вивчених $[6,8,11]$. При цьому використання вправ 3 елементами гри у футбол для психофрізичного розвитку дитини надає значні можливості [12].

Зважаючи на практичну відсутність можливості проведення оздоровчих занять на основі застосування елементів гри у футбол 3 дітьми у закладі дошкільної освіти, особливою атрактивністю користуються дитячі футбольні клуби. Дослідники $[7,8]$ констатують, що застосування у закладах дошкільної освіти вправ 3 елементами гри у футбол 3 дітьми дошкільного віку має епізодичний характер, або вони не використовуються зовсім. Додаткової уваги потребує удосконалення організаційно-методичних засад організації оздорогвчо-рекреаційної рухової активності дітей старшого дошкільного віку в умовах дитячих футбольних клубів.

Дослідження виконано відповідно до плану НДР НУФВСУ на 20212025 рр. за темою «Теоретичні та технологічні засади оздоровчо-рекреаційної рухової активності та здорового способу життя різних груп населення» (номер держреєстрації 0121U107534).

Мета дослідження - розробити структуру і зміст фрітнес-програми для дітей старшого дошкільного віку, спрямованої на підвищення показників їхнього фізичного стану, та оцінити її ефективність. 
account age, interests, expectations and needs; description of health-related and recreational program for over-fives. The main methodological conditions were: taking into account the initial level of indicators of physical condition of over-fives, proper primary, operational and current medical and pedagogical control; taking into account the needs of children and the requests of families in the direction of health classes; creation of full program support of health-related and recreational classes; improvement of professional competence and qualification, methodical support of coaches who conduct classes according to the proposed program, creation of optimal conditions for the work of children's coaches; raising pedagogical literacy of parents on health issues; creating favorable conditions for personal development and creative self-realization of children involved in classes; flexibility and mobility of the program in response to changes that occur in children in the process of health-related and recreational activities.

Keywords: children's football clubs, conditions, model, organizational and methodological support.

Методи дослідження: теоретичний аналіз фрахової науково-методичної літератури та документальних матеріалів, соціологічні, педагогічні методи дослідження, метод кваліметрії, методи математичної статистики.

Результати дослідження та їх обговорення. У ході нашої наукової роботи було проведено експертну оцінку за методом переваги (ранжирування), (як експерти були залучені 11 осіб (педагогічні працівники закладів дошкільної освіти, керівники спортивнорозважальних та оздоровчих центрів, науковці - розробники методик та матеріалів для закладів дошкільної освіти). Також було здійснено анкетування, яке проводили з вихователями, інструкторами з фрізичної культури дошкільних установ 3 метою виявлення особливостей організації оздоровчих занять у закладах дошкільної освіти на основі використання спортивних ігор і можливості впровадження програми із застосуванням елементів гри у футбол. Систематизацію матеріалу і первинну статистичну обробку було виконано за допомогою таблиць Microsoft巴Excel 2010.

Переважна більшість експертів $(90,9 \%)$ рекомендували удосконалювати механізми моніторингу оцінювання фрізичного стану дітей дошкільного віку шляхом організації їх належної діагностики та контролю, а також загострили увагу на ефективності урізноманітнення форм цілеспрямованого оздоровчо-виховного впливу, зокрема, шляхом організації індивідуальних занять, проведення гурткової (секційної, студійної) роботи. Крім того, 81,8 \% експертів переконані в ефективності активізації взаємодії з батьками, розширення переліку форм роботи з ними та створенні від- повідних умов для забезпечення регулярної рухової активності дітей дошкільного віку у цілорічному режимі, а 72,7 \% шлях до удосконалення організації оздоровчо-рекреаційної діяльності дітей дошкільного віку в умовах клубних занять вбачають у впровадженні наукових новацій, кращого досвіду з питань фрізичного розвитку дітей дошкільного віку в практику роботи дитячих футбольних клубів та родинного виховання. Виявилося, що, з точки зору 18,2 \% опитаних, організаційно-методичне забезпечення оздоровчо-рекреаційної діяльності дітей дошкільного віку в умовах клубних занять є достатньо сорормованим, проте 81,8 \% з них вважають, що його варто модернізувати 3 урахуванням здобутків науково-педагогічної науки. Варто вказати, що усі опитувані переконані, що традиційні заходи з організації оздоровчо-рекреаційної діяльності дітей дошкільного віку в умовах спортивно-оздоровчих та розважальних центрів потребують корекції та удосконалення.

Отримані результати покладені нами в основу удосконалення організаційно-методичного забезпечення оздоровчо-рекреаційної діяльності дитячих фрутбольних клубів. Як дієвий засіб підвищення ефективності організаційно-методичного забезпечення ми використали модель, яка включала чотири блоки: організаційний, діагностичний, програмно-методичний та контрольний (рис. 1).

Організаційний блок передбачає оцінку матеріально-технічних умов дитячого футбольного клубу, можливостей кадрового забезпечення, можливостей впровадження оздоровчорекреаційних програм для дітей старшого дошкільного віку.
Діагностичний блок передбачає визначення показників фрізичного стану дітей старшого дошкільного віку, опитування батьків про особливості рухової активності дітей, їхні інтереси та уподобання.

Програмно-методичний блок містить програму занять 3 використанням засобів спортивної анімації «FOOTBALL STARS» та заняття за програмою «FOOTBALL CLUB», також включає інфрормаційно-освітню складову, що має на меті підвищення педагогічної грамотності батьків 3 питань здоров'язбереження, а також курс для підвищення рівня знань дитячих тренерів $з$ питань безпеки проведення занять та використання засобів оздоровчо-рекреаційної рухової активності під час занять з даним контингентом.

Контрольний блок включає оцінку змін у показниках фрізичного стану дітей старшого дошкільного віку, рівня їх задоволеності від участі в програмах 3 використанням засобів оздоровчо-рекреаційної рухової активності, за необхідності - внесення коректив у програми занять.

Визначено такі технологічні умови для реалізації організаційно-методичного забезпечення оздоровчорекреаційних занять в умовах дитячих футбольних клубів:

Перша умова - вивчення наявної матеріально-технічної бази, ознайомлення та опис простору, споруд, інвентарю й обладнання, які можуть бути використані для оздоровчорекреаційних занять.

Друга умова - проведення анкетування та опитування батьків дітей для визначення спрямованості програми 3 урахуванням віку дитини, її інтересів, очікувань та потреб.

Третя умова - опис оздоровчорекреаційної програми для дітей старшого дошкільного віку. Для кожного заняття вказано перелік конкретних заходів, їх тривалість, місце проведення. Для фрормування й задоволення інтересу дітей до участі в таких заняттях здійснювали урізноманітнення використовуваних анімаційних заходів.

Четверта умова - інформування батьків і дітей про зміст, переваги 


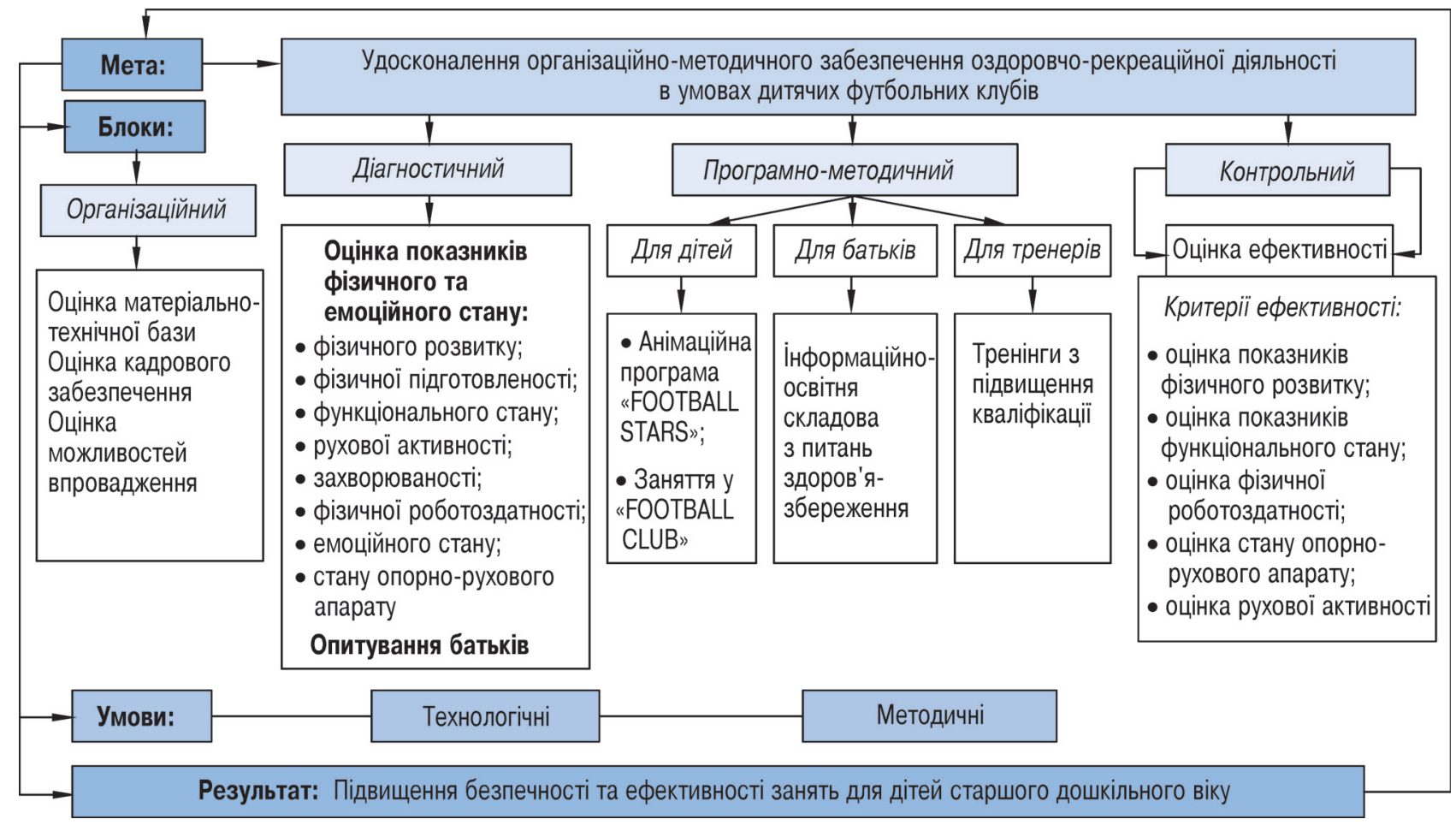

Рисунок 1 - Структура моделі організаційно-методичного забезпечення оздоровчо-рекреаційної діяльності дитячого футбольного клубу

й привабливі характеристики авторської програми занять $з$ елементами фрутболу.

П'ята умова - тестування та опитування учасників занять програми Основними формами контролю виступають:

- первинний - здійснюється перед початком проведення занять для визначення вихідного рівня показників фрізичного стану дітей старшого дошкільного віку;

- оперативний - проводиться після кожного анімаційного заняття, при цьому визначається рівень задоволеності осіб, кількість залучених до анімаційних програм та частота їх участі в анімаційних заходах і з'ясовуються нові інтереси й побажання відвідувачів;

- поточний - через 10-12 тижнів виконання програми; до уваги беруться показники психоемоційного та фуннціонального стану організму, рухової активності й виявлення змін у веденні здорового способу життя тих, хто бере участь в анімаційних заходах; перевіряється есективність засобів, методів та організаційних форм і визначається необхідність корекції;

- підсумковий - здійснюється після завершення програми (10 місяців); при цьому зіставляються вихідні показники кількості залучених до анімаційних програм та частоти їх участі в анімаційних заходах, рівня задоволеності, рівня рухової активності й морфрофункціонального та емоційного стану осіб, які брали участь у програмі, за тими критеріями ефективності, які були визначені.

Шоста умова - внесення змін до змісту та розкладу занять у межах анімаційної програми, яка реалізується. Відповідно до показників оперативного й поточного контролю, вносили корективи в підбір заходів, методів та організаційних фрорм для подальших занять 3 використанням засобів ффутболу. За підсумками реалізації цієї програми ссормовано рекомендації до спрямованості, розкладу й характеристики рекреаційних заходів для занять програми спортивної анімації нового сезону.

Основними методичними умовами реалізації програми оздоровчорекреаційних занять в умовах дитячого фрутбольного клубу виступали:

- урахування вихідного рівня показників фізичного стану дітей старшого дошкільного віку, належний первинний, оперативний та поточний лікарсько-педагогічний контроль;
- урахування потреб дітей та запитів родин у спрямованості оздоровчих занять;

- створення повного програмного супроводу оздорово-рекреаційних занять;

- підвищення фрахової компетентності та кваліфікації, методичний супровід тренерів, які проводять заняття за запропонованою програмою, створення оптимальних умов для роботи дитячих тренерів;

- створення сприятливих умов для особистісного становлення та творчої самореалізації дітей, залучених до занять;

- гнучкість та мобільність програми у реагуванні на зміни, які відбуваються 3 дітьми у процесі оздоровчорекреаційних занять.

Результативність запропонованих рекомендацій 3 удосконалення організаційно-методичного забезпечення оздоровчо-рекреаційної діяльності дітей старшого дошкільного віку в умовах дитячих фрутбольних клубів оцінювали на основі забезпечення належного рівня безпечності оздоровчих занять та ефективності відповідно до критеріїв, визначених експертами, а саме підвищення рівня рухової активності, гар- 
монійний фрізичний розвиток, корекція порушень опорно-рухового апарату, покращення функціонального стану основних систем організму, нормалізація емоційного стану дітей старшого дошкільного віку, підвищення рівня фізичної підготовленості.

Дискусія. Нами застосовано експертну оцінку для визначення причин, що не сприяють ефективному забезпеченню оздоровчо-рекреаційної діяльності дітей дошкільного віку у дитячих фрутбольних клубах. Подібні підходи довели свою ефективність у багатьох наукових роботах [3, 4, 9, 16]. Узгоджена думка експертів ( $\mathrm{W}=0,79 ; \mathrm{p}<0,05)$ засвідчила такі причини, що знижують ефективність: відсутність чіткої моделі організаційно-методичного забезпечення оздоровчо-рекреаційної діяльності, відсутність стійкої системи педагогічного контролю в процесі оздоровчо-рекреаційних занять, малоефективне дидактичне наповнення програм занять. На думку експертів, недостатньо обґрунтованим виглядає застосування програм оздоровчорекреаційної спрямованості, через ігнорування важливих її складових оцінки умов впровадження на базі футбольних клубів, моніторингу показників фрізичного стану. Експерти вказують на недостатньо обґрунтовані критерії ефективності.

Враховуючи результати констатуючого експерименту та опитування батьків і експертів, нами визначено шляхи підвищення ефективності організаційно-методичного забезпечення оздоровчо-рекреаційної діяльності на базі дитячого фуутбольного клубу. Науково обгрунтовано та розроблено модель організаційно-методичного забезпечення, в основу якої покладено чотири блоки, а саме, організаційний, діагностичний, програмно-методичний та контрольний. Ефективність блочного принципу побудови досліджували у ряді наукових робіт $[6,11,13,15]$.

Як складову розробленої моделі теоретично обґрунтовано, розроблено та впроваджено програму оздоровчорекреаційних занять «Football Stars» 3 використанням елементів гри у футбол. Як основні засоби використовували серію ігрових вправ з футбольним м'ячем: естафети, рухливі ігри, конкурси, спортивні вікторини, роз- важальні заходи, свята, сюжетнорольові ігри. Діти дошкільного віку, які проявили підвищений інтерес до занять фрутболом, мали можливість відвідувати додатково заняття у «Football club», що були спрямовані на початкове навчання гри у футбол. Використання засобів спортивних ігор i, зокрема засобів футболу, в оздоровчих програмах для дітей старшого дошкільного віку довело свою ефективність у багатьох наукових дослідженнях $[5,7,10-12,17]$.

Важливим для комплексного впливу на розвиток дитини є належний рівень теоретичної підготовленості батьків. На це звертається увага у спеціальній літературі [18]. Тому для підвищення рівня поінформованості батьків 3 питань здоров'язбереження було розроблено інформаційноосвітню складову, що включала основи теоретичних знань 3 питань рухового режиму дітей, раціонального харчування, загартування тощо.

Дослідники вбачають проблемним недостатній рівень підготовленості дитячих тренерів до впровадження оздоровчо-рекреаційної діяльності [16]. Тому для підвищення рівня знань дитячих тренерів з питань безпеки проведення занять та використання засобів оздоровчо-рекреаційної рухової активності під час занять з даним контингентом проводили тренінги, ефективність яких підтверджена у наукових роботах [7, 14].

Результати проведеного дослідження підтвердили та доповнили вже відомі розробки, а також сприяли отриманню нових даних про проблеми, що вивчалися. До нових результатів роботи належать: теоретичне обґрунтування моделі організаційнометодичного забезпечення оздоровчо-рекреаційної діяльності дитячих футбольних клубів, що включає організаційний, діагностичний, програмно-методичний та контрольний блоки та опрацювання технологічних і методичних умов її реалізації для підвищення безпечності та ефективності занять 3 дітьми дошкільного віку; обгрунтування цілісного підходу до програмно-методичного забезпечення оздоровчо-рекреаційної діяльності в умовах дитячих футтольних клубів.

Проведені дослідження сприяли обґрунтуванню ряду нових нау- кових положень, які в цілому дозволили вирішити важливе наукове завданя, пов'язане 3 удосконаленням організаційно-методичного забезпечення оздоровчо-рекреаційної діяльності дитячих фрутбольних клубів.

Висновки. 3 точки зору експертів встановлено, що організаційнометодичне забезпечення оздоровчорекреаційної діяльності дітей дошкільного віку в умовах клубних занять $€$ достатньо сорормованим, проте експерти вважають, що його варто модернізувати з урахуванням здобутків науково-педагогічної науки. Відповідно до отриманих результатів дослідження здійснено теоретичне обґрунтування моделі організаційнометодичного забезпечення оздоровчо-рекреаційної діяльності дитячих футбольних клубів, що включає організаційний, діагностичний, програмно-методичний та контрольний блоки, та опрацювання технологічних і методичних умов її реалізації для підвищення безпечності та есективності занять $з$ дітьми дошкільного віку; обґрунтування цілісного підходу до програмно-методичного забезпечення оздоровчо-рекреаційної діяльності в умовах дитячих футбольних клубів. Для визначення ефективності впровадження моделі визначено технологічні та методичні умови її реалізації на базі дитячих футбольних клубів. Розроблені заходи сприяли удосконаленню організаційно-методичного забезпечення дитячого футбольного клубу. Авторська програма занять для дітей старшого дошкільного віку на базі дитячих футбольних клубів сприяла покращенню показників фізичного стану дітей, підвищенню рівня їхньої рухової активності, зміцненню опорно-рухового апарату, поліпшенню емоційного стану, підвищенню показників фрізичної підготовленості, зниженню захворюваності. Зазначене свідчить про ефективність запропонованої моделі та дозволяє її рекомендувати до впровадження у практичну діяльність дитячих футбольних клубів.

Перспективи подальших досліджень пов'язані 3 обґрунтуванням та розробкою програм оздоровчорекреаційних занять 3 елементами футболу для дітей шкільного віку на базі дитячих клубних об'єднань. 
Конфлікт інтересів. Автори заявляють, що відсутній будь-який конфрлікт інтересів.

\section{ЛITEРАТУРА}

1. Андрєєва ОВ. Розробка та впровадження технології проектування активної рекреаційно діяльності різних груп населення. Спортивний вісник Придніпров'я. 2015;1:4-9.

2. Андрєєва 0, Сухомлинов Р. Організація оздоровчо-рекреаційної рухової активност дітей дошкільного віку в умовах клубних занять. Теорія і методика фрізичного виховання спорту. 2016;3:29-32.

3. Андрєєва 0, Сухомлинов Р. Чинники, що лімітують залучення дітей дошкільного віку до оздоровчо-рекреаційної рухової активності. В Огаренко ВМ, та ін., редактори. Актуальні про блеми фрізичного виховання, реабілітації, спор ту і туризму: тези доповідей 6-ї Міжнародно наук.-практ. конф.; 2016 Жовт 20-21; Запо ріжжя. Запоріжжя: КПУ; 2016.150-1. 1.

4. Андрєєва 0, Чернявський М. Проблеми та перспективи провадження рекреаційно оздоровчих занять в загальноосвітніх школах. Теорія і методика фрізичного виховання і спорту. 2005;1:45-8.

5. Бабачук ЮМ. Аналіз змісту сучасних про грам, спрямованих на навчання дошкільників ігор 3 елементами спорту. Науковий часопис НПУ ім. М. П. Драгоманова. Серія 15: Науково педагогічні проблеми фрізичної культури (Фізична культура і спорт). 2014; 3К(44)14:44-8.

6. Воропай С, Сукачов О. Вплив занять з елементами баскетболу на фізичну підготовленість дітей 5 років. В: Приступа $€$, редактор. Молода спортивна наука України: зб. наук. праць. Львів. 2014;T. 2:14-20.

7. Ермакова ЮН. Методика фризкультурных занятий с детьми 5-7 лет на основе использования элементов игры в футбол [автореферат] Шуя: Шуйский государственный педагогический университет. 2010. 24 с

8. Конох О€. Комплексне використання засобів спортивних ігор у підвищенні фрізичного стану дітей 5-6 років [дисертація]. Запоріжжя. 2014. 301 c.

9. Сухомлинов Р, Андрєєва О. Особливості клубної форми організації рекреаційно оздоровчих занять дітей дошкільного віку. Молодіжний науковий вісник Східно-європейського національного університету імені Лесі Українки. 2017;25:67-71.

10. Томенко ОА, Старченко АЮ. Фізкультурна освіта старших дошкільнят: інноваційна технологія. Суми. 2016. 154 с.

\section{ІНФОРМАЦІЯ ПРО АВТОРІВ}

Сухомлинов Рудольф Олегович https://orcid.org/0000-0002-4086-1433, rud.sukhomlynov@ gmail.com

Блистів Тарас Васильович https://orcid.org/0000-0002-0681-2494, blistivtv@gmail.com

Національний університет фрізичного виховання і спорту України 03150, Київ, вул. Фізкультури, 1

\section{INFORMATION ABOUT THE AUTHORS}

Sukhomlinov Rudolf https://orcid.org/0000-0002-4086-1433, rud.sukhomlynov@gmail.com Blystiv Taras https://orcid.org/0000-0002-0681-2494, blistivtv@gmail.com

National University of Ukraine on Physical Education and Sport 03150, Kyiv, Fizkul'tury str., 1
Mizhnarodnoi nauk.-prakt. konf.; 2016 0ct 20-21; Zaporizhzhia: KPU; 2016.150-1. 1

4. Andreiva 0, Cherniavskyi M. Problems and prospects of introducing recreational and healthrelated classes in general schools. Teoriia i metodyka fizvykhovannia i sportu. 2005;1:45-8.

5. Babachuk IM. Analysis of the modern program content focused on teaching preschoolers games with elements of sport. Naukovyi chasopys Natsionalnoho pedahohichnoho universytety imeni M. P. Drahomanova. 2014; 3K(44)14:44-8.

6. Voropay S, Sukachov O. Impact of classes with elements of basketball on physical fitness of children aged 5. In: Prystupa I, editor. Moloda sportyvna nauka Ukrainy. Lviv. 2014; Vol. 2:14-20.

7. Yermakova YN. Methods of physical culture lessons with children aged 5-7 based on usage of football elements [author's abstract]. Shuya: Shuysky pedagogicheskiy universitet. 2010. 24 p.

8. Konokh 0I. Complex usage of sports games for improving physical condition of children aged 5-6 [dissertation]. Zaporizhzhia. 2014. 301 p.

9. Sukhomlynov R, Andreieva 0. Features of club form of organizing recreational and healthrelated classes for preschoolers. Molodizhnyi naukovyi visnyk Skhidnoievropeyskoho universytetu im. Lesi Ukrainky. 2017;25:67-71.

10. Tomenko OA, Starchenko Al. Physical culture education of over-fives: innovation technology. Sumy. 2016. 154 p.

11. Cherednichenko PP. Physical rehabilitation of over-fives with flat foot in conditions of sports and game center [author's abstract]. Kyiv. 2018. 20 p.

12. Alesi $M$, Bianco $A$, Luppina $G, P a l-$ ma A, Pepi A. Improving Children's Coordinative Skills and Executive Functions: The Effects of a Football Exercise Program. Percept Mot Skills. 2016 Feb;122(1):27-46. doi: 10.1177/ 0031512515627527.

13. Andrieieva OV, Sainchuk OM. Approach to evaluating health level and adaptation possibilities in schoolchildren. Pedagogics, psychology, medical-biological problems of physical training and sports, 2014;2:3-8. doi:10.6084/ m9.figshare.923507

14. Byl J, Kloet BV. Physical Education for Homeschool, Classroom, and Recreation Settings: 102 Games With Variations. United States: United Graphics\$2014. p. 217

15. Coleman B, Dyment JE. Factors that limit and enable preschool-aged children's physical activity on child care centre playgrounds. Journal of Early Childhood Research. 2013;11(3):203-221. doi: 10.1177/1476718X12456250

16. Kashuba V, Andrieieva O, Yarmolinsky L, Karp I, Kyrychenko V, Goncharenko Y, Rychok T, Nosova N. Measures to prevent functional muscular disorders in sports training of 7-9-year-old football players. Journal of Physical Education and Sport (JPES). 2020; 20 (1): 366-371. DOI:10.7752/ jpes.2020.s1052.

17. Liannoi Y, Liannoi M, Maksymenko L, Kopytina Y. Recreational technologies (Elements of Floorball Sports) for children aged 5 and 6 years. Kultura fizycna. Czestochow. 2018;1(17):69-78.

18. Moskalenko N, Polyakova A, Mykytchyk 0 . Methodological Bases of the Motor Activity Organization among Preschoolers Depending on the Physical State Level. Physical Education, Sports and Health Culture in Modern Society, 2019;2(46):28-34. https://doi.org/10.29038/22207481-2019-02-28-34 